\title{
The safe use of compost derived from municipal solid waste depends on its composition and conditions of application
}

\author{
Margarida Arrobas $^{1}$ (0) | Jéssica Thais Nepomuceno Carvalho ${ }^{2}$ | Soraia Raimundo $^{1}$ | \\ Giovana Poggere $^{2}$ | Manuel Ângelo Rodrigues ${ }^{1}$ (
}

${ }^{1}$ Centro de Investigação de Montanha (CIMO), Instituto Politécnico de Bragança, Bragança, Portugal

${ }^{2}$ Universidade Tecnológica Federal do Paraná, Medianeira, Brazil

\section{Correspondence}

Margarida Arrobas, Centro de Investigação de Montanha (CIMO), Instituto Politécnico de Bragança, Campus de Santa Apolónia, 5300-253 Bragança, Portugal.

Email: marrobas@ipb.pt

Funding information

Foundation for Science and Technology, Grant/Award Number: UIDB/00690/2020

\begin{abstract}
Municipal solid waste compost (MSWC) is a source of organic C and other nutrients, which, when free from potential contaminants, can be used as a soil amendment. This study was carried out over three years in a vineyard with soil $\mathrm{pH}$ close to neutral under an experimental design consisting of two treatments (with and without MSWC). Application of MSWC is currently authorized under national legislation to be used in vineyards, orchards and forests at a maximum rate of $10 \mathrm{tha}^{-1}$ year $^{-1}$. In this study, for experimental purposes, a double rate (20 $\mathrm{t} \mathrm{ha}^{-1}$ year $^{-1}$ ) was used. The accumulated grape yield increased in the amended plot by $28 \%$ and the dry biomass of weeds between rows by $119 \%$. The MSWC significantly increased some relevant soil properties such as organic $\mathrm{C}, \mathrm{pH}$, cation exchange capacity (CEC) and extractable $\mathrm{P}, \mathrm{K}$ and $\mathrm{B}$. The concentration of $\mathrm{K}$ increased significantly in several tissues, and the concentration of $\mathrm{P}$ decreased. However, the concentration of $\mathrm{K}, \mathrm{P}$ and other essential nutrients in the leaves remained within their sufficiency ranges. Tissue levels of heavy metals $(\mathrm{Cr}, \mathrm{Cd}, \mathrm{Pb}$ and $\mathrm{Ni}$ ) did not increase with the MSWC application, and the values in the pulp remained below the limits established for foodstuffs. The results from this study indicate that the continuous application of the MSWC does not seem to be sustainable, because of the risk of causing nutritional disorders. Products with similar composition should therefore be used only on more acidic soils and should never exceed the legally established rates.
\end{abstract}

\section{K E Y W O R D S}

grape yield, heavy metals, plant nutritional status, soil fertility, Vitis vinifera

\section{1 | INTRODUCTION}

Organic matter plays a central role in soil fertility. Of the many benefits provided for plant growth, the role of organic matter in creating aggregate stability is well known, with a major effect in aerating clay soils and increasing the water-holding capacity of sandy soils, as well as generally supporting the biological activity of the soil, which is responsible for nutrient cycling (Weil \& Brady, 2017).
In many regions of the world, soil organic matter content is low, because of either natural ecological restrictions or agricultural practices, which do not promote the deposition of organic debris in the soil but rather favour their mineralization. In the Mediterranean region, land that supports most of the perennial crops, such as olive, almond and vine, is often exposed to severe soil erosion conditions, mainly because of steep slopes and reduced soil cover, and invariably presents low levels of organic 
matter (Almagro et al., 2016; Bombino et al., 2021; Torres et al., 2018).

In the past, the loss of soil organic matter was usually balanced by the application of farmyard manure. With the advent of the mechanization of agriculture, farms became more specialized and no longer had manure. Today's urban societies, however, generate a lot of waste with recycling potential, including organic waste. Unfortunately, in industrialized countries, a significant proportion of municipal solid waste (MSW) is sent for incineration or is landfilled (Murtaza et al., 2019; Rockwood et al., 2012). However, growing concerns about air quality and greenhouse gas emissions are increasing the interest in using agricultural soils as a means of MSW disposal (Weil \& Brady, 2017).

Properly composted MSW can have a fertilizer value equivalent to farmyard manure. It can contribute to the introduction of organic carbon (C) into the soil and the recycling of other nutrients, promoting soil fertility and enhancing crop productivity (Grau et al., 2017; Leogrande et al., 2016; Murtaza et al., 2019). However, materials from undifferentiated collections of waste can present quality problems, the greatest of which is the risk of containing heavy metals (Deepesh et al., 2016; Liu et al., 2019). In the European Union (EU), Regulation (EU) 2019/1009 (EU, 2019) may restrict or prevent the use of MSW depending on its content of heavy metals.

'Resíduos do Nordeste' is an intermunicipal company that manages waste from a group of 13 municipalities in the north of Portugal. It produces a composted material from the collection of undifferentiated solid waste, after separation of metals, glass, cardboard and plastics, which is placed on the market to be used as an organic amendment. According to national legislation (Decree-Law $\mathrm{n}^{\mathrm{o}}$ 103/2015), this organic amendment, named 'Ferti Trásos-Montes', is classified as Class IIA, which indicates a risk of containing heavy metals above a certain limit. A class IIA product can be used on perennial shrub and tree crops, such as orchards and vines, and in forestry, but not on edible vegetable species. Even in authorized situations, the annual rate cannot exceed $10 \mathrm{tha}^{-1}$ fresh weight.
Considering that the usual soil organic matter content in perennial crops in the region is low (Arrobas et al., 2018; Rodrigues \& Arrobas, 2020; Rodrigues et al., 2015), and given also the scarcity of farmyard manure, the possibility of using this resource is very attractive for some farmers. In this study, results are reported of the effect of the application of the compost 'Ferti Trás-os-Montes' in an experimental vineyard at the rate of $20 \mathrm{tha}^{-1}$ over three consecutive years. Several variables were determined such as grape yield, the elemental composition of plant tissues (including the levels of heavy metals), several soil properties, and also the dry matter yield and the elemental composition of the herbaceous vegetation that were found to develop between the rows. The aim of the study was to establish guidelines for the safe use of this organic amendment, so that it may be regarded as a resource, and not as a potential contaminant of the environment or the food chain.

\section{MATERIALS AND METHODS}

\section{$2.1 \quad$ Study site}

The field trial took place during the growing seasons of 2017-2019, at the experimental farm of Sta Apolónia $\left(41^{\circ} 47^{\prime} 50.4^{\prime \prime} \mathrm{N} ; 6^{\circ} 45^{\prime} 57.5^{\prime \prime} \mathrm{W}\right)$, in Bragança, NE, Portugal. The region has a Mediterranean climate influenced by the Atlantic regime. Annual precipitation and air temperature are $772.8 \mathrm{~mm}$ and $12.7^{\circ} \mathrm{C}$, respectively. Records of average air temperature and monthly precipitation during the experimental period are shown in Figure 1.

The study area is part of the upper allotone complex, belonging to the Galicia/Trás-os-Montes area of the Iberian Massif. Soil mineralogy is based on metamorphosed ultramafic rocks (peridotitic rocks, serpentinized peridotites and some quartz) (Pereira, 2019). The soil where the vineyard is planted is classified as an Eutric Cambisol and is loamy sand-textured (clay, 11.4\%; lime, 14.5\%; and sand, $74.1 \%$ ). At the start of the field trial, the $0.0-$ to $0.2-\mathrm{m}$ soil layer showed $8.7 \mathrm{~g} \mathrm{~kg}^{-1}$ organic $\mathrm{C}$, a pH $\left(\mathrm{H}_{2} \mathrm{O}\right)$ of 6.2 , with levels of extractable phosphorus $(\mathrm{P})$ (sodium bicarbonate method) and potassium (K) (ammonium lactate method)

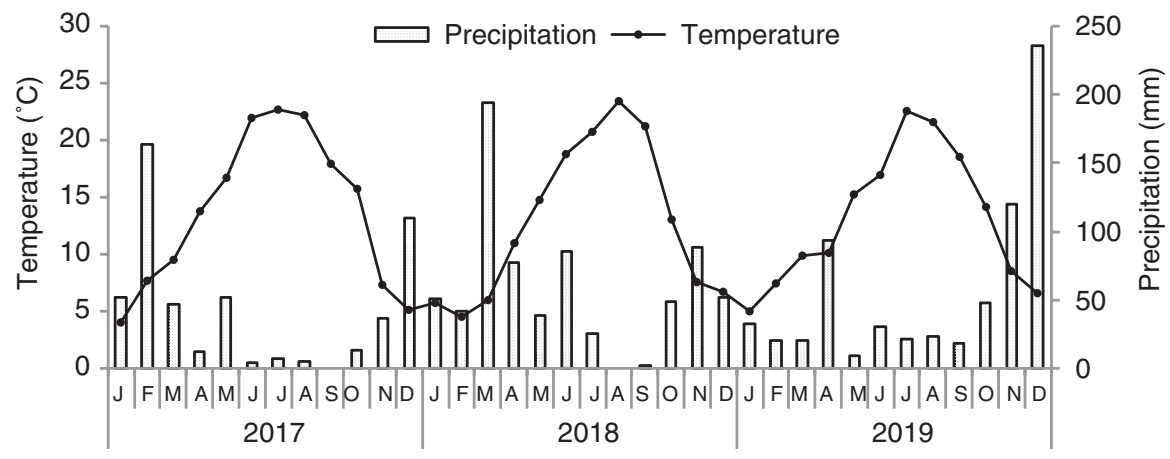

FI G UR 1 Monthly precipitation and average air temperature during the experimental period in the weather station of Sta Apolónia farm 
low (14.1 $\mathrm{mg} \mathrm{P} \mathrm{kg}^{-1}$ ) and very high (272.7 $\mathrm{mg} \mathrm{K}_{2} \mathrm{O} \mathrm{kg}^{-1}$ ), respectively, and a cation exchange capacity (CEC) of $16.6 \mathrm{cmol}_{\mathrm{c}} \mathrm{kg}^{-1}$.

\subsection{Experimental apparatus}

The experiment was arranged as a completely randomized design with two treatments (MSWC and a non-amended control), with three replications, each one consisting of nine contiguous and homogeneous grape vines.

The organic amendment used in this study was a compost produced from the organic fraction of undifferentiated MSW by the intermunicipal company 'Resíduos do Nordeste', which manages waste from 13 municipalities in the northern region of Portugal. According to national legislation (Decree-Law no 103/2015), the compost obtained belongs to class IIA, to which correspond maximum allowable values of cadmium (Cd), lead $(\mathrm{Pb})$, copper $(\mathrm{Cu})$, chromium $(\mathrm{Cr})$, mercury $(\mathrm{Hg})$, nickel $(\mathrm{Ni})$ and zinc $(\mathrm{Zn})$ of 3, 300, 400, 150, 3, 200 and $1000 \mathrm{mg} \mathrm{kg}^{-1}$ dry weight, respectively. Taking into account the levels of heavy metals that the composts of class IIA may contain, they can be used on tree and shrub crops such as orchards and vineyards and also on forest species, but not on horticultural crops (Decree-Law no 103/2015). The amount of amendment that can be used is also restricted to $10 \mathrm{t} \mathrm{ha}^{-1}$ year $^{-1}$.

The composition of the MSWC used in this study in each of the three years is shown in Table 1. Despite the legal limits for the use of this compost being $10 \mathrm{t} \mathrm{ha}^{-1}$ year ${ }^{-1}$ of fresh material, for the experimental purposes of this study, a double rate of $20 \mathrm{t} \mathrm{ha}^{-1}$ year $^{-1}$ was used. The application of the compost was carried out by the middle of March, and the product was evenly spread over the ground of the vineyard, being subsequently incorporated with a cultivator to a depth of ca. $0.0-0.1 \mathrm{~m}$.

The plot of the vineyard used in this study consisted of cv. Viosinho Blanc grafted onto Richter 110. The cv. Viosinho is of medium vigour, the clusters and berries are small, and the skin is yellowish green. The vines are spaced at $2.5 \mathrm{~m}$ between rows and $1.4 \mathrm{~m}$ within rows ( 2860 vines per hectare). The vineyard has been pruned as Guyot double, with an average crop load of 24 buds per vine. The shoots are supported by three horizontal wires placed at 0.6, 0.9 and $1.2 \mathrm{~m}$ height from the ground. The vineyard was planted in 1997, and it has been rainfed managed.
TABLE 1 General properties of the compost applied over the three years of the study

\begin{tabular}{|c|c|c|c|}
\hline & 2017 & 2018 & 2019 \\
\hline Moisture (\%) ${ }^{\mathrm{a}}$ & 31.7 & 21.6 & 12.6 \\
\hline Conductivity $\left(\mathrm{mS} \mathrm{cm}^{-1}\right)^{\mathrm{b}}$ & 5.6 & 6.2 & 4.6 \\
\hline $\mathrm{pH}\left(\mathrm{H}_{2} \mathrm{O}\right)^{\mathrm{c}}$ & 8.2 & 7.8 & 7.9 \\
\hline Organic carbon $\left(\mathrm{g} \mathrm{kg}^{-1}\right)^{\mathrm{d}}$ & 236.1 & 247.0 & 218.1 \\
\hline Nitrogen $\left(\mathrm{g} \mathrm{kg}^{-1}\right)^{\mathrm{e}}$ & 17.5 & 15.7 & 16.8 \\
\hline Phosphorus $\left(\mathrm{g} \mathrm{kg}^{-1}\right)^{\mathrm{f}}$ & 4.6 & 4.7 & 3.2 \\
\hline Potassium $\left(\mathrm{g} \mathrm{kg}^{-1}\right)^{\mathrm{g}}$ & 14.1 & 15.9 & 13.6 \\
\hline Calcium $\left(\mathrm{g} \mathrm{kg}^{-1}\right)^{\mathrm{g}}$ & 74.3 & 63.0 & 64.8 \\
\hline Magnesium $\left(\mathrm{g} \mathrm{kg}^{-1}\right)^{\mathrm{g}}$ & 8.3 & 8.3 & 7.9 \\
\hline Boron $\left(\mathrm{mg} \mathrm{kg}^{-1}\right)^{\mathrm{f}}$ & 49.0 & 74.4 & 65.3 \\
\hline Copper $\left(\mathrm{mg} \mathrm{kg}^{-1}\right)^{\mathrm{g}}$ & 265.7 & 183.9 & 169.5 \\
\hline Iron $\left(\mathrm{mg} \mathrm{kg}^{-1}\right)^{\mathrm{g}}$ & 12341.4 & 11895.7 & 12751.1 \\
\hline Zinc $\left(\mathrm{mg} \mathrm{kg}^{-1}\right)^{\mathrm{g}}$ & 487.9 & 419.0 & 528.0 \\
\hline Manganese $\left(\mathrm{mg} \mathrm{kg}^{-1}\right)^{\mathrm{g}}$ & 474.8 & 569.7 & 414.2 \\
\hline Cadmium $\left(\mathrm{mg} \mathrm{kg}^{-1}\right)^{\mathrm{g}}$ & 2.7 & 2.9 & 2.6 \\
\hline Chromium $\left(\mathrm{mg} \mathrm{kg}^{-1}\right)^{\mathrm{g}}$ & 57.7 & 40.2 & 93.8 \\
\hline $\operatorname{Nickel}\left(\mathrm{mg} \mathrm{kg}^{-1}\right)^{\mathrm{g}}$ & 44.8 & 77.9 & 60.0 \\
\hline Lead $\left(\mathrm{mg} \mathrm{kg}^{-1}\right)^{\mathrm{g}}$ & 198.8 & 149.2 & 101.8 \\
\hline \multicolumn{2}{|c|}{${ }^{\mathrm{a}}$ Gravimetry. } & \multicolumn{2}{|c|}{${ }^{b} 1: 5$ dry substrate to water extract. } \\
\hline \multicolumn{4}{|l|}{ d Dry combustion. } \\
\hline \multicolumn{4}{|l|}{ é Kjeldahl. } \\
\hline $\begin{array}{l}\text { Colorimetry. } \\
{ }^{g} \text { Atomic absorption spectropho }\end{array}$ & & & \\
\hline
\end{tabular}


From the beginning, the fertilizer application plan consisted of the application of a compound NPK fertilizer at a rate of $20 \mathrm{~kg} \mathrm{ha}^{-1}$ of $\mathrm{N}, \mathrm{P}\left(\mathrm{P}_{2} \mathrm{O}_{5}\right)$ and $\mathrm{K}\left(\mathrm{K}_{2} \mathrm{O}\right)$. From 2015 , $\mathrm{N}$ and $\mathrm{K}$ continued to be applied at a rate equivalent to that mentioned above, supplemented with $1 \mathrm{~kg}$ of $\mathrm{B} \mathrm{ha}^{-1}$, but $\mathrm{P}$ was no longer applied. These changes were made after the results of a study of nutrient balance carried out on this plot had become known (Arrobas et al., 2014). Organic amendments have never been applied to this plot.

During the experimental period, the soil was tilled twice a year by cultivator, the first pass being done in March for the incorporation of the compost, and the second pass late in April to control the weeds. Regarding other cropping practices, such as crop protection, the vineyard was managed according to the best practice in the region. During the experimental period, no fertilizers were applied other than the MSWC.

\section{3 | Sampling and analytical determinations}

Samples of leaves were taken annually at the onset of the ripening of the grapes (veraison) for analysis. The leaves sampled were those located opposite bunches of grapes. Each sample was divided into two samples for separate analysis of the whole leaf (blade +petiole) and petioles alone. At harvest, the production of grapes from each experimental unit was weighed fresh. In the last year, samples of grapes were taken to the laboratory and separated into stems, cuticles, seeds and pulp for analysis of the elemental composition. In May 2019, just before the second pass of cultivation, weeds were also sampled for determination of dry matter yield and tissue elemental composition. Vegetation was cut from samples of $0.25 \mathrm{~m}^{2}$ after a metal grid $(0.5 \times 0.5 \mathrm{~m})$ had been randomly thrown on the ground.

The samples of leaves, petioles, stems, cuticles, seeds and weeds were oven-dried at $70^{\circ} \mathrm{C}$, and then ground. The elemental composition of pulp was determined as fresh. Elemental analyses of tissue samples were performed by the Kjeldahl $(\mathrm{N})$, colorimetry (B and $\mathrm{P}$ ) and atomic absorption spectrophotometry $(\mathrm{K}, \mathrm{Ca}, \mathrm{Mg}, \mathrm{Fe}, \mathrm{Mn}, \mathrm{Cu}, \mathrm{Zn}$, $\mathrm{Ni}, \mathrm{Cr}, \mathrm{Cd}$ and $\mathrm{Pb}$ ) methods (Temminghoff \& Houba, 2004) after tissue samples had been previously digested with nitric acid in a microwave. In addition to these variables, the MSWC was also analysed for moisture (gravimetry), conductivity (1:5 dry substrate to water extraction) and organic $\mathrm{C}$ (dry combustion).

In October 2019, the soil was also sampled at two depths (0-0.1 $\mathrm{m}$ and $0.1-0.2 \mathrm{~m})$ in the space between the rows where the organic amendment had been applied. Each soil sample was prepared as a composite sample by collecting and mixing soil from 10 points in each of the three replications. These soil samples were oven-dried at $40^{\circ} \mathrm{C}$ and sieved through a $2-\mathrm{mm}$ mesh. The dried and sieved soil samples were submitted to the following analytical determinations: (1) $\mathrm{pH}\left(\mathrm{H}_{2} \mathrm{O}\right.$ and $\left.\mathrm{KCl}\right)$ (by potentiometry); (2) organic C (Walkley-Black method); (3) CEC (ammonium acetate, $\mathrm{pH} 7.0$ ); (4) extractable $\mathrm{P}$ (sodium bicarbonate at $\mathrm{pH} 8.5$, Olsen method); (5) extractable $\mathrm{K}$ (ammonium lactate solution at pH 3.7, Egner-Riehm method); (6) extractable B (hot water and azomethine- $\mathrm{H}$ method); and (7) extractable $\mathrm{Fe}, \mathrm{Mn}, \mathrm{Zn}, \mathrm{Cu}, \mathrm{Ni}, \mathrm{Cr}, \mathrm{Cd}$ and $\mathrm{Pb}$ (ammonium acetate and EDTA, determined by atomic absorption spectrometry). In the initial samples, there were also determined (8) clay, silt and sand fractions (Robinson pipette method). Methods 1-4 and 6-8 are fully described by Van Reeuwijk (2002) and method 5 by Balbino (1968).

\subsection{Data analysis}

The data were tested for normality and homogeneity of variances using the Shapiro-Wilk test and Bartlett's test, respectively. The comparison of the effect of the two fertilizer treatments was provided by the Student's test $(p<.05)$.

\section{3 | RESULTS}

\subsection{Plant growth and yield}

Grape yield increased significantly in the MSWC treatment in comparison with the untreated control in the harvest of 2018 and also when analysed as cumulative yield over the three years of the experiment (Figure 2). The increase in grape yield over the three harvests in the MSWC treatment reached $28.1 \%$ in comparison with the control. Pruning wood, a measure of plant vigour, did not vary significantly between the two treatments, but the average values were slightly higher in the MSWC in comparison with the control treatment.

Weeds in the MSWC treatment produced more than twice the dry biomass than in the control treatment. Although no detailed analysis of the floristic composition had been carried out in the spring of 2019, before the weed control cultivation, a significant variation was observed in the composition of the groundcover. In the MSWC treatment, two species showed great dominance in the biomass produced, namely Erodium moschatum (L.) L'Hér and Stellaria media (L.) Vill., whereas in the control treatment, the dominant species was Senecio vulgaris L. 

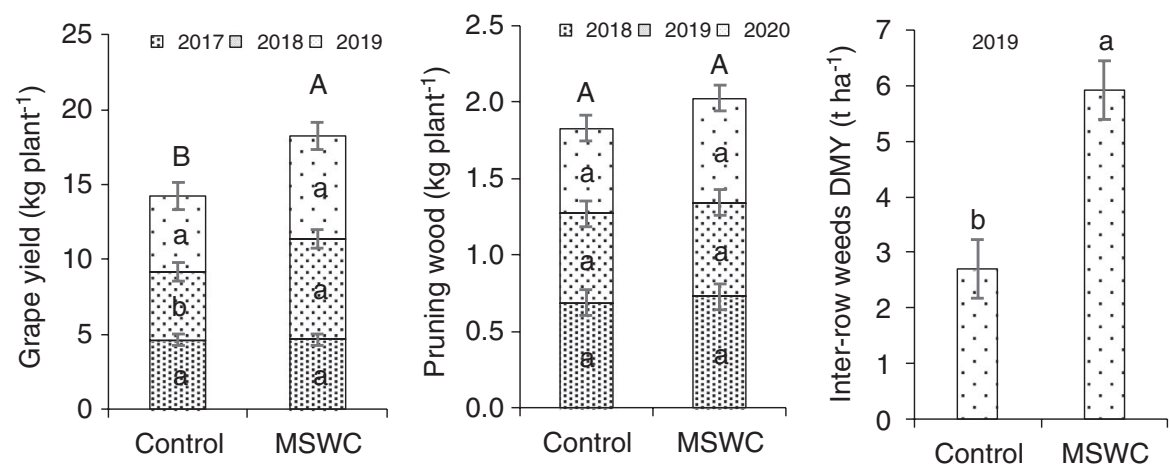

F I G U RE 2 Grape yield (fresh weight), pruning wood (dry weight) and inter-row weeds' dry matter yield (DMY) in the control and municipal solid waste compost (MSWC) treatments. Means associated with different letters (lower case for each year and uppercase for accumulated total) are statistically different $(p<.05)$. Vertical bars are the standard errors

\section{2 $\quad$ Soil properties}

The soil properties at the end of the experiment were analysed in the layers $0.0-0.1$ and $0.1-0.2 \mathrm{~m}$. Figure 3 shows the results of the $0.0-$ to $0.1-\mathrm{m}$ layer. The soil properties in the $0.1-$ to $0.2-\mathrm{m}$ layer did not show any significant variation between treatments, and their contribution to this study was considered to be low and therefore not shown.

Soil $\mathrm{pH}$ increased significantly with the application of MSWC (7.35) compared with the control treatment (7.05). Also, the contents of organic $\mathrm{C}$ and Kjeldahl $\mathrm{N}$ in the soil increased significantly with the application of the organic amendment, varying from 11.9 and $1.8 \mathrm{~g} \mathrm{~kg}^{-1}$ to 16.4 and $2.7 \mathrm{~g} \mathrm{~kg}^{-1}$, respectively. The values of $\mathrm{P}$ extracted with sodium bicarbonate increased from 14.6 to $31.0 \mathrm{mg} \mathrm{P} \mathrm{kg}^{-1}$ with the application of MSWC and those of potassium extracted with ammonium lactate from 313.3 to $545.3 \mathrm{mg}$ $\mathrm{K}_{2} \mathrm{O} \mathrm{kg}$. The values of CEC also increased significantly with the application of MSWC and the soil B levels. Fe showed a slight decrease in average values with MSWC but without significant differences to the control. $\mathrm{Zn}$ increased markedly with MSWC from 4.2 to $34.8 \mathrm{mg} \mathrm{kg}^{-1}$. $\mathrm{Mn}, \mathrm{Cu}$ and $\mathrm{Ni}$ decreased significantly with the application of MSWC. $\mathrm{Cd}, \mathrm{Pb}$ and $\mathrm{Cr}$ showed an increasing trend, but only $\mathrm{Pb}$ values showed statistical difference.

\section{3 | Elemental composition of plant tissues}

In general terms, tissue $\mathrm{N}$ concentrations did not vary significantly with soil treatments. In the cuticle, the MSWC treatment showed even lower $\mathrm{N}$ values than the control (Table 2). $\mathrm{P}$ decreased significantly in most of the plant tissues (leaf, petiole, cuticle and seed) with the application of MSWC, in comparison with the control. In turn, $\mathrm{K}$ increased significantly with MSWC treatment in the leaves and petioles, but did not vary significantly in the other tissues. $\mathrm{Ca}$ and $\mathrm{Mg}$ levels usually did not vary significantly with soil treatments. The exceptions were $\mathrm{Ca}$ levels in the seeds and Mg levels in pruning wood, where the values were significantly higher in the control, in comparison with the MSWC treatment. Tissue B levels did not vary significantly with soil treatments. Fe and Mn levels in plant tissues also did not usually vary significantly with soil treatments. The exception was the stem, whose values of both nutrients were higher in the MSWC treatment. In most of the tissues, $\mathrm{Zn}$ and $\mathrm{Cu}$ levels also did not vary with soil treatments. However, $\mathrm{Zn}$ and $\mathrm{Cu}$ levels in pruning wood were significantly higher in the MSWC treatment. The levels of $\mathrm{Cd}$ in the stem and cuticle were significantly lower in the MSWC treatment, but not significantly different in the other tissues. The levels of $\mathrm{Cr}$ and $\mathrm{Pb}$ varied significantly between treatments only in stems, the higher values being found in the control treatment. The concentrations of Ni were significantly lower in the MSWC treatment in comparison with the control in the petioles, cuticle and pulp. In the other plant tissues, Ni values did not vary significantly with soil treatments.

The elemental composition of dry biomass of weeds is presented in Figure 4. The concentrations of $\mathrm{N}, \mathrm{Mg}$, $\mathrm{Fe}, \mathrm{Mn}, \mathrm{Cu}, \mathrm{Cr}$ and $\mathrm{Ni}$ in the aboveground dry biomass of weeds decreased significantly with the application of MSWC. The average values of $\mathrm{P}, \mathrm{Zn}, \mathrm{Cd}$ and $\mathrm{Pb}$ were also lower in the MSWC treatment but without significant differences to the control. $\mathrm{K}$ was the only element whose concentration in the dry biomass of weeds increased significantly in the MSWC, in comparison with the control treatment.

\section{DISCUSSION}

The vines treated with MSWC significantly increased their production, and there was a tendency to increase their vigour as measured in pruning wood. The dry matter 

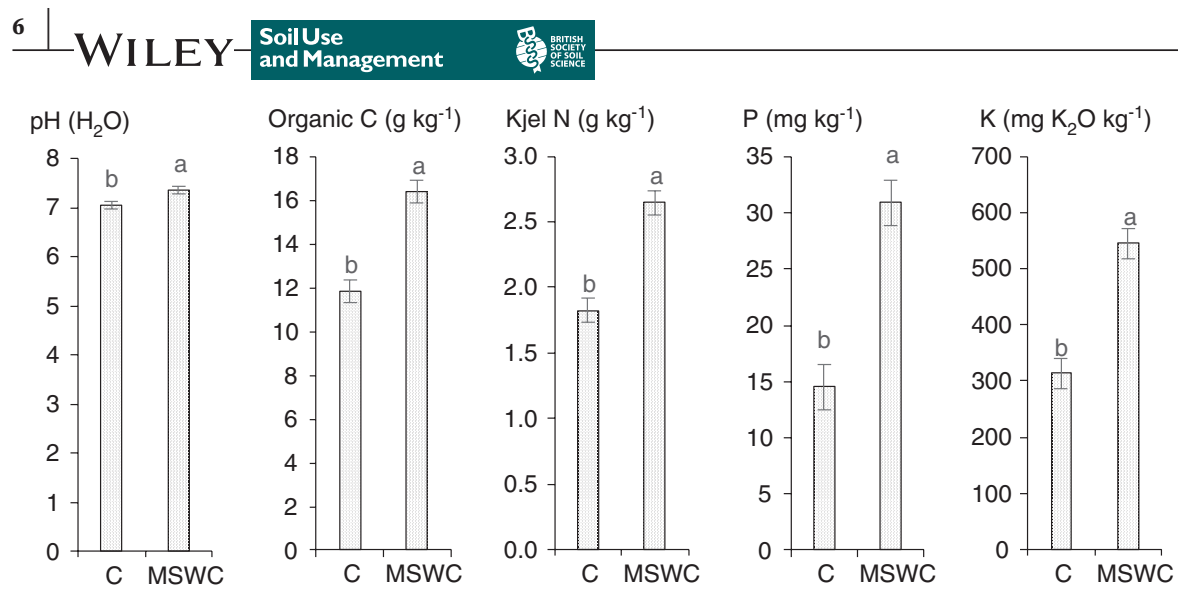

FIG URE 3 pH $\left(\mathrm{H}_{2} \mathrm{O}\right)$, organic carbon (C), Kjeldahl nitrogen $(\mathrm{N})$, phosphorus $(\mathrm{P})$, potassium $(\mathrm{K})$, cation exchange capacity (CEC), boron (B), iron (Fe), zinc $(\mathrm{Zn})$, copper $(\mathrm{Cu})$, manganese $(\mathrm{Mn})$, cadmium (Cd), nickel (Ni), lead ( $\mathrm{Pb}$ ) and chromium (Cr) in the 0 - to $0.1-\mathrm{m}$ soil layer in the control (C) and municipal solid waste compost (MSWC) treatments. Means associated with different letters are statistically different $(p<.05)$. Vertical bars are the standard errors
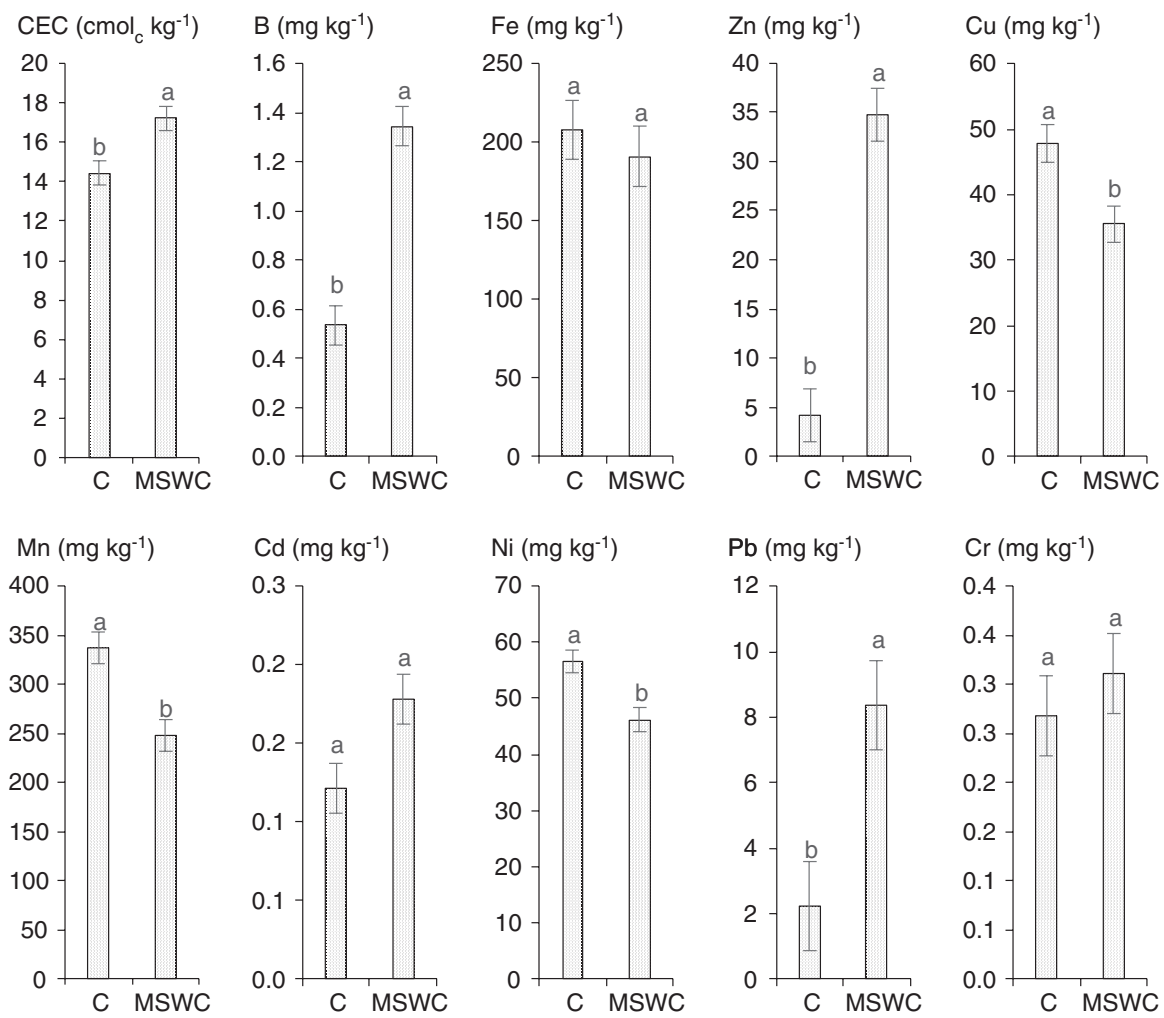

produced by the herbaceous vegetation also increased with the application of MSWC. However, from the variables measured, and mainly from the concentration of nutrients in the tissues, it is not easy to explain this stimulus to productivity. The concentration of most of the nutrients in the leaves did not vary significantly with the treatments and, when variation was observed, the values remained within the sufficiency ranges as reported by Bryson et al. (2014). Even in the herbaceous vegetation, a significant increase in the concentration of nutrients in the tissues by the application of MSWC occurred only for K. However, organic matter can have a beneficial effect on plants far beyond the availability of nutrients, by influencing many other physical, chemical and biological soil properties (Rees et al., 2001; Santos, 2015; Weil \& Brady, 2017). Bearing in mind that this vineyard is rainfed managed, and the availability of water greatly determines the performance of plants grown in a Mediterranean environment
(Gonçalves et al., 2020; Pérez-Álvarez et al., 2021), the better water conditions in the amended plots may have had a positive effect on vegetation growth. Moreover, with the application of organic matter to the soil there is always expected a certain 'manuring effect' on plants that is difficult to achieve by providing nutrients exclusively through the application of mineral fertilizers (Weil \& Brady, 2017).

Soil $\mathrm{pH}$ increased significantly in the MSWC treatment compared with the control. The decomposition of organic matter by microorganisms releases high levels of $\mathrm{CO}_{2}$ in the soil air, producing carbonic acid $\left(\mathrm{H}_{2} \mathrm{CO}_{3}\right)$. Soil microbial activity may generate many other organic acids, some of which are highly acidic such as the carboxylic and phenolic groups in humus produced during litter breakdown. Acting together, these factors give rise to a tendency for acidification when organic matter is applied to the soil (Weil \& Brady, 2017). However, $\mathrm{H}_{2} \mathrm{CO}_{3}$ is a weak acid, so its acidifying effect is reduced (Pines et al., 2016). 


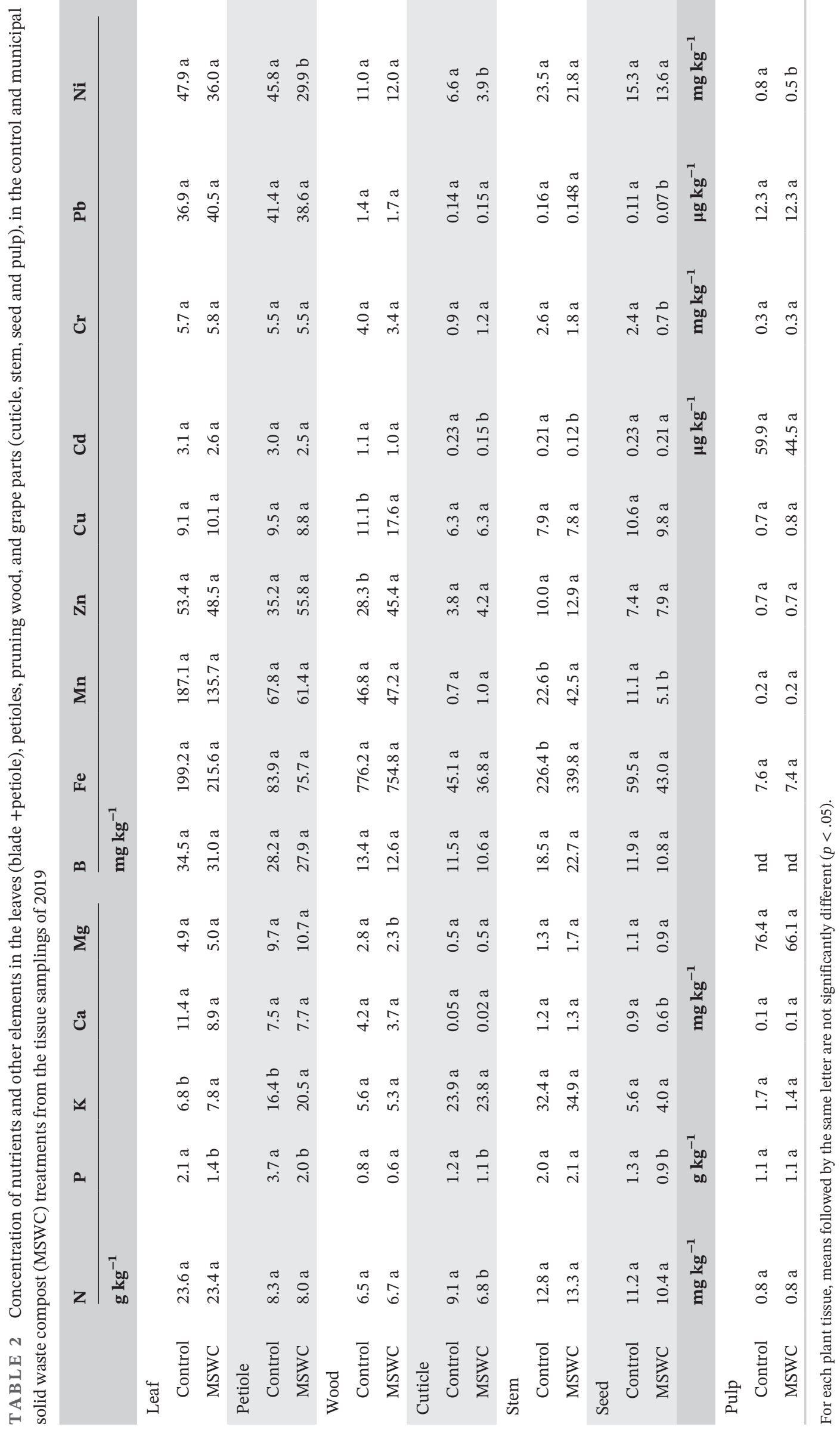



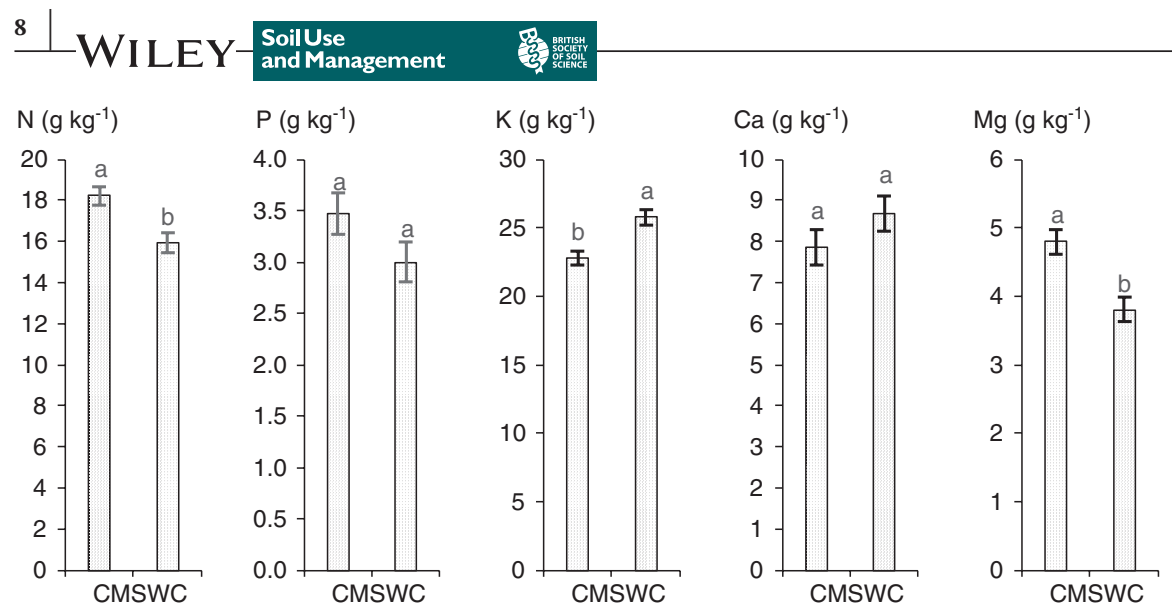

F I G URE 4 Nitrogen (N), phosphorus $(\mathrm{P})$, potassium $(\mathrm{K})$, calcium $(\mathrm{Ca})$, magnesium $(\mathrm{Mg})$, boron $(\mathrm{B})$, iron $(\mathrm{Fe})$, manganese $(\mathrm{Mn})$, zinc $(\mathrm{Zn})$, copper $(\mathrm{Cu})$, cadmium (Cd), chromium ( $\mathrm{Cr}$ ), lead $(\mathrm{Pb})$ and nickel $(\mathrm{Ni})$ concentrations in spontaneous vegetation sampled between rows in the control (C) and municipal solid waste compost (MSWC) treatments. Means associated with different letters are statistically different $(p<.05)$. Vertical bars are the standard errors
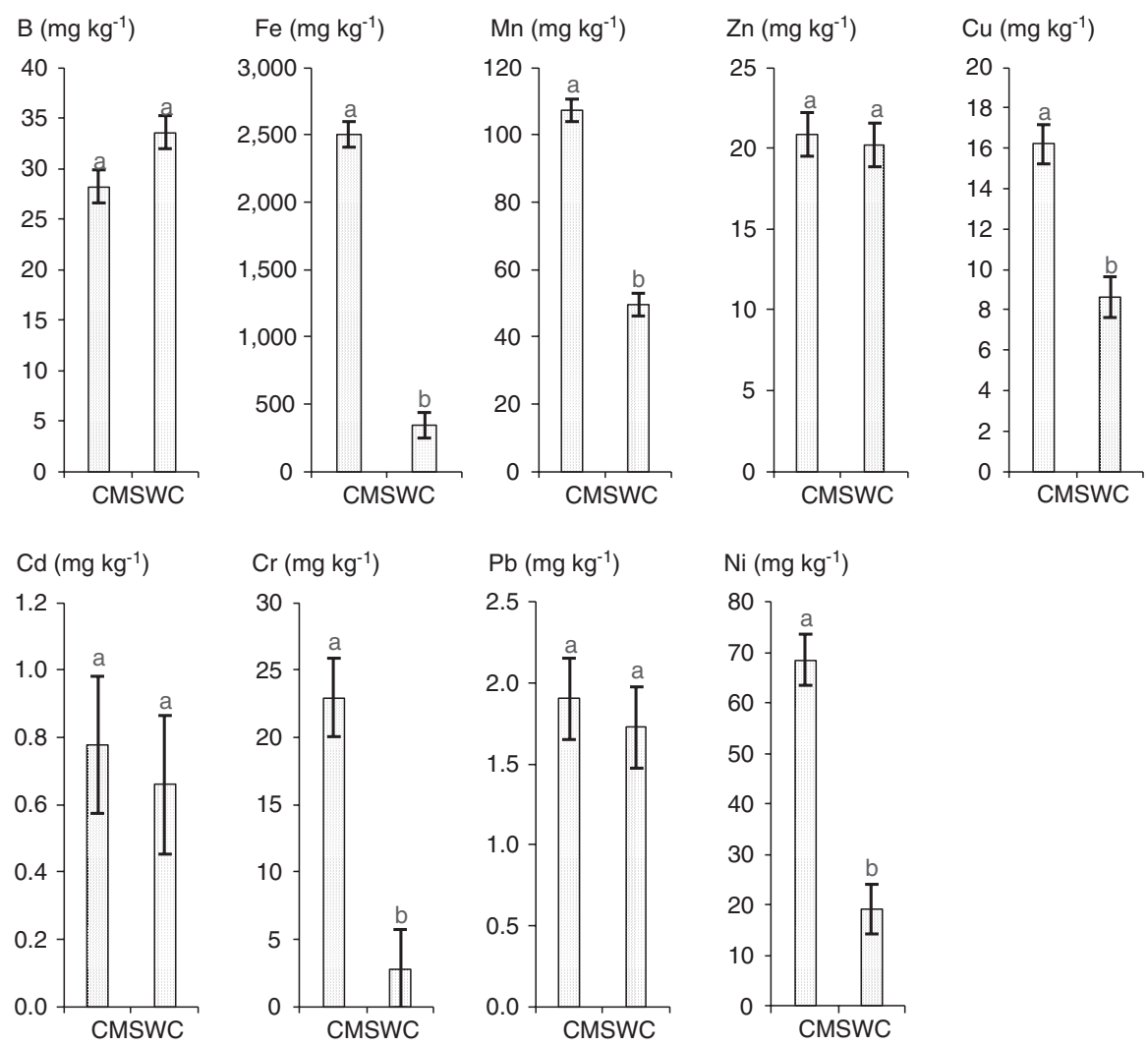

On the other hand, the organic matter content in the soil increased with the application of MSWC, which may indicate a low mineralization rate of the organic substrate, probably because of their relatively low $\mathrm{N}$ levels (Table 1). Furthermore, the original $\mathrm{pH}$ of this organic substrate was high and higher than the $\mathrm{pH}$ of the soil. Thus, the increase in $\mathrm{pH}$ can be explained as a direct response to the application of an organic material rich in non-acidic cations, in particular $\mathrm{Ca}$, whose values were particularly high (Table 1 ), with this effect prevailing over the acidifying effect of the decomposition of organic matter.

The $\mathrm{N}$ concentration in the vine leaves and in many other tissues did not vary significantly between treatments. In weeds, the $\mathrm{N}$ concentration was lower in the plots amended with MSWC in comparison with the control. Part of the applied $\mathrm{N}$ may have undergone biotic immobilization, which corresponds to $\mathrm{N}$ retained in microbial biomass (Cao et al., 2020; Myrold \& Bottomley, 2008), this being one of the reasons for the apparent reduced soil $\mathrm{N}$ availability in the amended plots. This thesis is supported by the increase in organic $\mathrm{C}$ and Kjeldahl $\mathrm{N}$ in the soil, revealing that part of the applied $\mathrm{N}$ is still in organic form. The increase in the production of grapes and, above all, the increase in weeds' dry matter yield gave rise to a dilution effect, which normally contributes to the reduction of the concentration of nutrients in the tissues (Arrobas et al., 2018; Jarrell \& Beverly, 1981). Many other inefficiencies of $\mathrm{N}$ use may have contributed to the result. The MSWC was incorporated in the 0.0- to $0.1-\mathrm{m}$ soil layer with a cultivator. Soil surface-applied, or poorly incorporated, organic materials can allow high $\mathrm{N}$ loss through ammonia volatilization, especially when the soil 
pH is high (Huijsmans et al., 2003; Francis et al., 2008). $\mathrm{N}$ in the $\mathrm{NH}_{4}^{+}$form can be fixed or entrapped in certain 2:1-type clay minerals (Kissel et al., 2008; Havlin et al., 2014). Although the soil only contained $11.4 \%$ clay, it is possible that some $\mathrm{N}$ was trapped in the clay as $\mathrm{NH}_{4}^{+}$. Soilapplied organic materials strongly increase the potential for denitrification, because of the increased oxygen consumption by heterotrophic microorganisms and higher availability of electrons (Coyne, 2008). Since there was abundant precipitation following the application of compost, the loss of $\mathrm{N}$ by denitrification may have played an important role in the apparent inefficiency of $\mathrm{N}$ use. $\mathrm{N}$ loss by nitrate leaching from agro systems is also known to be common (Lu et al., 2021; Sigler et al., 2020). In this experiment, however, $\mathrm{N}$ loss as dissolved organic $\mathrm{N}$ (DON) may have been more relevant because of the high rates of MSWC applied. When organic matter is applied to the soil, soluble $\mathrm{N}$-containing organic compounds may also be available to be leached out. It has been shown that $25 \%$ of the N carried out by the Mississippi River into the Gulf of Mexico is DON (Weil \& Brady, 2017). On the other hand, dissolved organic $\mathrm{N}$ can enhance $\mathrm{N}$ losses as nitrous oxide $\left(\mathrm{N}_{2} \mathrm{O}\right)$ (Guo et al., 2020), increasing the contribution of denitrification to the overall, apparent, reduced $\mathrm{N}$ use efficiency.

Soil-extractable P increased markedly with the application of MSWC. However, in the vine tissues there was observed a consistent decrease in $\mathrm{P}$ concentrations, with significant differences in leaves, petioles, cuticles and seeds. In the herbaceous vegetation, there was also observed a decrease in the concentration of $\mathrm{P}$ with the application of MSWC, although without significant differences to the control treatment. In alkaline soils, the availability of P is very low (White, 2012). Even P added as soluble fertilizer soon reacts with the $\mathrm{Ca}^{2+}$ in solution to form calcium phosphate compounds that become increasingly insoluble over time and are quite stable at high $\mathrm{pH}$ levels (Weil \& Brady, 2017). The application of MSWC, by introducing large amounts of $\mathrm{Ca}$ and raising the $\mathrm{pH}$, made $\mathrm{P}$ less available to the plants even though it continues to be solubilized from soil samples by sodium bicarbonate, the extracting agents used in this study (Arrobas and Coutinho, 2002). The increase in $\mathrm{pH}$, and insolubilization of $\mathrm{P}$ by the application of MSWC, may not have been a nutritional problem for the vine as the concentration of $\mathrm{P}$ in the leaves remained within the sufficiency range as reported by Bryson et al. (2014). The inorganic P that precipitated as calcium phosphates should first be seen as valuable reserves of $\mathrm{P}$ in the soil that will be released as the mineralization of organic matter occurs and the $\mathrm{pH}$ decreases.

Soil K increased significantly with the application of MSWC. A tendency for a $\mathrm{K}$ increase in vine tissues was also found, with significant differences to the control treatment in leaves and petioles. In the herbaceous vegetation, a significant difference in tissue $\mathrm{K}$ concentrations was also found with the higher values recorded in the amended plots. K does not form part of organic structures (Hawkesford et al., 2012), so the nutrient contained in MSWC could quickly enter the soil solution, contributing to the increase in the concentration of $\mathrm{K}$ in the tissues. The application of MSWC also increased the CEC and the $\mathrm{K}$ adsorbed in the negative charges. This, as well as the possibility that part of the $\mathrm{K}$ can also be fixed in the clay minerals (Kissel et al., 2008; Havlin et al., 2014), may constitute an important reserve of $\mathrm{K}$ in the soil, protected from leaching, and reflecting the increase in $\mathrm{K}$ detected in the soil analysis.

The application of MSWC increased CEC. When $\mathrm{pH}$ increases, more functional groups undergo dissociation of $\mathrm{H}^{+}$ions, leaving behind an increasing number of negatively charged sites (Weil \& Brady, 2017). However, the increase in CEC did not cause an increase in the concentration of $\mathrm{Ca}$ and $\mathrm{Mg}$ in the tissues, probably because of a dilution effect that usually results from either the stimulus to dry matter yield (Arrobas et al., 2018; Jarrell \& Beverly, 1981) and/or eventually through ion antagonism caused by $\mathrm{K}$ that occurs when $\mathrm{K}$ supply is abundant (Hawkesford et al., 2012).

Soil B levels increased significantly with the application of MSWC. However, B concentrations in vine tissues and in the herbaceous vegetation did not vary significantly. Although soil B measured by extraction with hot water increased in the MSWC plot, the bioavailability of the element does not seem to have increased. With an alkaline $\mathrm{pH}, \mathrm{B}$ is adsorbed by organic colloids with a binding strength even greater than that of inorganic colloids, which means that B availability to plants decreases with increasing soil pH (Goldberg, 1997; Goldberg \& Suarez, 2012; Gupta, 2007). However, this result can also be interpreted as positive. The MSWC did not increase the levels of B in plant tissues, but they were found to be within the sufficiency range of $30-100 \mathrm{mg} \mathrm{kg}^{-1}$ as reported by Bryson et al. (2014). B adsorbed by organic colloids can be seen as a reserve, which may benefit the plants as the organic matter undergoes mineralization.

The application of MSWC did not influence Fe levels in the soil, but caused a significant decrease in $\mathrm{Mn}$ and $\mathrm{Cu}$, and a significant increase in $\mathrm{Zn}$. The concentrations of these micronutrient cations did not vary consistently between treatments in the vine tissues, although in the herbaceous vegetation there was found to be a decrease in their concentrations by the application of MSWC, with significant differences for $\mathrm{Fe}, \mathrm{Mn}$ and $\mathrm{Cu}$. The application of organic matter contributes to the formation of fulvic and humic acids that can give rise to chelates with metal 
ions such as $\mathrm{Fe}, \mathrm{Mn}, \mathrm{Cu}$ and $\mathrm{Zn}$, which may increase their availability to plants (Marschner \& Rangel, 2012). On the other hand, the increase in $\mathrm{pH}$ tends to reduce the uptake of Fe, $\mathrm{Mn}, \mathrm{Cu}$ and $\mathrm{Zn}$ (Broadley et al., 2012; White, 2012). Under the conditions of this experiment, the effect of the $\mathrm{pH}$ increase seems to have been more prevalent since the concentration of nutrients in the tissues was reduced. $\mathrm{Zn}$, however, showed a slightly different behaviour, with an increase within the soil and a smaller reduction within tissues compared with $\mathrm{Fe}, \mathrm{Mn}$ and $\mathrm{Cu}$. In agricultural soils, P-Zn interactions are well established. High application rates of $\mathrm{P}$ fertilizers to soils low in available $\mathrm{Zn}$ can induce Zn deficiency (Broadley et al., 2012). In this experiment, $P$ uptake in the plots treated with MSWC was significantly reduced, which may have favoured the uptake of $\mathrm{Zn}$, and thus, this element did not suffer a reduction as occurred with $\mathrm{Fe}, \mathrm{Mn}$ and $\mathrm{Cu}$. However, these interactions will also have been of low physiological significance for the grapevine, since the concentration of these nutrients was never shown to be below the lower limit of their sufficiency ranges (Bryson et al., 2014).

Among the metals $\mathrm{Cd}, \mathrm{Cr}, \mathrm{Pb}$ and $\mathrm{Ni}$, only the levels of $\mathrm{Pb}$ increased significantly in the soil with the application of MSWC, probably because $\mathrm{Pb}$ was the element with the highest concentration in the applied MSWC. On the other hand, the concentration of these metals in the tissues of the vine tended not to vary with the treatments, and when this was observed, they tended to be lower in the plants treated with MSWC. With the application of MSWC, Ni was the clearest example whose levels were significantly lower in petiole, cuticle and pulp. The results of the concentration of metals in the herbaceous vegetation follow the same trend as in the tissues of the vine. The fact that the application of MSWC did not cause an increase in the concentration of metals in the tissues may be because of the increase in alkalinity, which causes the dissociation of $\mathrm{H}^{+}$from $\mathrm{OH}$ groups from organic matter; this allows greater adsorption of metals, thereby reducing their solubility (Alleoni et al., 2005; Neumann \& Römheld, 2012). However, the levels of metals in the grape pulp were found to be below the values established for most edible products by the Codex Alimentarius Commission (FAO/ WHO, 2018), and there seems to be no fear of using this organic amendment in vines, even at double the rate that is legally permitted.

\section{CONCLUSIONS}

The application of MSWC caused a general positive effect on most soil properties, including an increase in soil organic matter, CEC and extractable $\mathrm{P}, \mathrm{K}$ and $\mathrm{B}$. The concentrations of some nutrients, such as $\mathrm{K}$, increased in plant tissues, and those of others, such as P, decreased, but in general, the values of essential nutrients remained within the sufficiency ranges set for the vine. The concentrations of heavy metals in plant tissues tended to decrease with the application of MSWC, and the levels in the pulp remained below the maximum values established as safe for food. In general, it was found that a pool of important nutrients was formed in the soil, because of the increase in organic matter and CEC, which may act as a reserve for these nutrients as the organic matter becomes mineralized. However, it does not appear to be sustainable to continue to repeat the application of this product every year at such high rates and in soils of neutral and alkaline $\mathrm{pH}$, because of the risks of causing nutritional disorders with the increase in soil $\mathrm{pH}$. The leaf $\mathrm{P}$ and $\mathrm{K}$ levels, for instance, decreased and increased, respectively, and can quickly be found out of their sufficiency ranges. On the other hand, even though problems with heavy metals were not observed, they continue to enter the soil, which may cause problems in the near future if MSWC ceases to be applied and a rapid mineralization of the organic substrate occurs. Based on these results, it can be inferred that the benefits of using a product with such characteristics would be optimized only if applied to more fundamentally acidic soils and providing they do not exceed the legally established rates.

\section{ACKNOWLEDGEMENTS}

This research was funded by the Foundation for Science and Technology (FCT, Portugal) and FEDER under Programme PT2020 for financial support to CIMO (UIDB/00690/2020).

The authors would also like to thank the intermunicipal company 'Resíduos do Nordeste' and Dr. Paulo Praça for the free supply of the compost that was used in this study.

\section{CONFLICT OF INTEREST}

The authors declare that they have no conflict of interest.

\section{DATA AVAILABILITY STATEMENT}

The data that support the findings of this study are available from the corresponding author upon reasonable request.

\section{ORCID}

Margarida Arrobas (1) https://orcid. org/0000-0002-4652-485X

Manuel Ângelo Rodrigues (1) https://orcid.

org/0000-0002-5367-1129

\section{REFERENCES}

Alleoni, L. R. F., Iglesias, C. S. M., Mello, S. C., Camargo, O. A., Casagrande, J. C., \& Lavorenti, N. A. (2005). Atributos do solo 
relacionados à adsorção de cádmio e cobre em solos tropicais. Acta Scientiarum Agronomy, 27(4), 729-737. https://doi. org/10.4025/actasciagron.v27i4.1348

Almagro, M., de Vente, J., Boix-Fayos, C., García-Franco, N., Aguilar, J. M., González, D., Solé-Benet, A., \& Martínez-Mena, M. (2016). Sustainable land management practices as providers of several ecosystem services under rainfed Mediterranean agroecosystems. Mitigation and Adaptation Strategies for Global Change, 21, 1029-1043.

Arrobas, M., \& Coutinho, J. (2002). Caracterização do fósforo em solos de Portugal. Revista Das Ciências Agrárias, XXV, 109-122.

Arrobas, M., Ferreira, I. Q., Afonso, S., \& Rodrigues, M. A. (2018). Sufficiency ranges and crop nutrient removals for peppermint (Mentha x piperita L.) established from field and pot fertilizer experiments. Communications in Soil Science Plant. Analysis, 49(14), 1719-1730. https://doi.org/10.1080/00103 624.2018.1474909

Arrobas, M., Ferreira, I. Q., Freitas, S., Verdial, J., \& Rodrigues, M. A. (2014). Guidelines for fertilizer use in vineyards based on nutrient content of grapevine parts. Scientia Horticulturae, 172, 191-198. https://doi.org/10.1016/j.scienta.2014.04.016

Balbino, L. R. (1968). La méthode Egner-Riehm et la détermination du phosfore et du potassium 'assimilável' des sols du Portugal. pp. 55-65. II Col. Medit Cont. Fert. Plantas Cultivadas.

Bombino, G., Denisi, P., Gómez, J. A., \& Zema, D. A. (2021). Mulching as best management practice to reduce surface runoff and erosion in steep clayey olive groves. International Soil and Water Conservation Research, 9(1), 26-36. https://doi.org/10.1016/j. iswcr.2020.10.002

Broadley, M., Brown, P., Cakmak, I., Rengel, Z., \& Zhao, F. (2012). Function of nutrients, micronutrients. In P. Marschner (Ed.), Marschner's mineral nutrition of higher plants (pp. 191-248). Elsevier.

Bryson, G., Mills, H. A., Sasseville, D. N., Jones, J. B. Jr, \& Barker, A. V. (2014). Plant analysis handbook III. A guide to sampling, preparation, analysis and interpretation for agronomic and horticultural crops. Micro-Macro Publishing Inc.

Cao, Y., Zhao, F., Zhang, Z., Zhu, T., \& Xiao, H. (2020). Biotic and abiotic nitrogen immobilization in soil incorporated with crop residue. Soil \& Tillage Research, 202, 104664. https://doi. org/10.1016/j.still.2020.104664

Coyne, M. S. (2008). Biological denitrification. In J. Schepers, \& W. R. Raun (Eds), Nitrogen in agricultural Systems (pp. 201-253). Agronomy Monograph n. ${ }^{\circ} 49$. ASA, CSSA, SSSA.

Decree-Law no 103/ 2015. Decreto-Lei $n^{0}$ 103/3015. Diário da República, $1 .^{a}$ série - N. ${ }^{o} 114$ - 15 de junho de 2015. Ministério da Economia.

Deepesh, V., Verma, V. K., Suma, K., Ajay, S., Gnanavelu, A., \& Madhusudanan, M. (2016). Evaluation of an organic soil amendment generated from municipal solid waste seeded with activated sewage sludge. Journal of Material Cycles and Waste Management, 18, 273-286. https://doi.org/10.1007/s1016 3-014-0329-8

EU (European Union). (2019). Regulation (EU) 2019/1009, of the European Parliament and the Council of 5 June 2019. Official Journal of European Union, 25(6), 2019.

FAO, WHO (Codex Alimentarius Commission). (2018). Joint FAO/ WHO food standards programme, codex committee on contaminants in foods. Food. CF/12 INF/1: 1-169.
Francis, D. D., Vigil, M. F., \& Mosier, A. R. (2008). Gaseous losses of nitrogen other than through denitrification. In J. S. Schepers, \& W. R. Raun (Eds.), Nitrogen in agricultural systems (pp. 255279). ASA, CSSA, SSSA.

Goldberg, S. (1997). Reactions of boron with soils. Plant and Soil, 193, 35-48.

Goldberg, S., \& Suarez, D. L. (2012). Role of organic matter on boron adsorption-desorption hysteresis of soils. Soil Science, 177, 417423. https://doi.org/10.1097/SS.0b013e318256bc0c

Gonçalves, A., Silva, E., Brito, C., Martins, S., Pinto, L., Dinis, L. T., Luzio, A., Martins-Gomes, C., Fernandes-Silva, A., Ribeiro, C., Rodrigues, M. A., Moutinho-Pereira, J., Nunes, F. M., \& Correia, C. M. (2020). Olive tree physiology and chemical composition of fruits are modulated by different deficit irrigation strategies. Journal of the Science of Food and Agriculture, 100, 682-694. https://doi.org/10.1002/jsfa.10064

Grau, F., Drechsel, N., Haering, V., Trautz, D., Weerakkody, W. J. S. K., Drechsel, P., Marschner, B., Dissanayake, D. M. P. S., \& Sinnathamby, V. (2017). Impact of fecal sludge and municipal solid waste co-compost on crop growth of Raphanus sativus L. and Capsicum annuum L. under stress conditions. Resources, 6, 26, 10.3390/resources6030026

Guo, B., Zheng, X., Yu, Z., Ding, H., Pan, B., Luo, S., \& Zang, Y. (2020). Dissolved organic carbon enhances both soil $\mathrm{N}_{2} \mathrm{O}$ production and uptake. Global Ecology and Conservation, 24, e01264. https://doi.org/10.1016/j.gecco.2020.e01264

Gupta, U. C. (2007). Boron. In A. V. Barker, \& D. J. Pilbeam (Eds.), Handbook of plant nutrition (pp. 241-277). CRC.

Havlin, J. L., Tisdale, S. L., Nelson, W. L., \& Beaton, J. D. (2014). Soil fertility and fertilizers, an introduction to nutrient management (8th ed.). Pearson Inc.

Hawkesford, M., Horst, W., Kichey, T., Lambers, H., Schjoerring, J., Skrumsager, M., \& White, P. (2012). Function of macronutrients. In P. Marschner (Ed.), Marschner's mineral nutrition of higher plants (pp. 135-189). Elsevier.

Huijsmans, J. F. M., Hol, J. M. G., \& Vermeulen, G. D. (2003). Effect of application method, manure characteristics, weather and field conditions on ammonia volatilization from manure applied to arable land. Atmospheric Environment, 37, 3669-3680. https://doi.org/10.1016/S1352-2310(03)00450-3

Jarrell, W. M., \& Beverly, R. B. (1981). The dilution effect in plant nutrition studies. Advances in Agronomy, 34, 197-224.

Kissel, D. E., Cabrera, M. L., \& Paramasivan, S. (2008). Ammonium, ammonia, and urea reactions in soils. In J. S. Schepers, \& W. R. Raun (Eds), Nitrogen in agricultural systems (pp. 101-155). ASA, CSSA, SSSA.

Leogrande, R., Lopedota, O., Vitti, C., Ventrella, D., \& Montemurro, F. (2016). Saline water and municipal solid waste compost application on tomato crop: Effects on plant and soil. Journal of Plant Nutrition, 39(4), 491-501. https://doi.org/10.1080/01904 167.2015.1084325

Liu, L., Wang, S., Guo, X., \& Wang, H. (2019). Comparison of the effects of different maturity composts on soil nutrient, plant growth and heavy metal mobility in the contaminated soil. Journal of Environmental Management, 250, 109525. https:// doi.org/10.1016/j.jenvman.2019.109525

Lu, J., Hu, T., Zhang, B., Wang, L., Yang, S., Fan, J., Yan, S., \& Zhang, F. (2021). Nitrogen fertilizer management effects on soil nitrate leaching, grain yield and economic benefit of summer maize 
in Northwest China. Agricultural Water Management, 247, 106739. https://doi.org/10.1016/j.agwat.2021.106739

Marschner, P., \& Rangel, Z. (2012). Nutrient availability in soils. In P. Marschner (Ed.), Marschner's mineral nutrition of higher plants (pp. 315-330), Elsevier.

Murtaza, B., Zaman, G., Imran, M., Shah, G. M., Amjad, M., Ahmad, N., Naeem, M. A., Zakir, A., Farooq, A., Ahmad, S., \& Murtaza, G. (2019). Municipal solid waste compost improves crop productivity in saline-sodic soil: A multivariate analysis of soil chemical properties and yield response. Communications in Soil Science Plant Analysis, 50(8), 1013-1029. https://doi. org/10.1080/00103624.2019.1603305

Myrold, D. D., \& Bottomley, P. Y. (2008). Nitrogen mineralization and immobilization. In J. S. Schepers, \& W. R. Raun (Eds), Nitrogen in agricultural systems (pp. 157-172). ASA, CSSA, SSSA.

Neumann, G., \& Romheld, V. (2012). Rhizosphere chemistry in relation to plant nutrition. In P. Marschner (Ed.), Marschner's mineral nutrition of higher plants (pp. 347-368). Elsevier.

Pereira, G. O. A. I. (2019). Estudo geológico do Alóctone Superior da Região de Alimonde (Bragança): implicações na geologia económica da região. MSc thesis. Universidade de Aveiro and Faculdade de Ciências da Universidade do Porto.

Pérez-Álvarez, E. P., Molina, D. S. I., Vivaldi, G. A., García-Esparza, M. J., Lizama, V., \& Álvarez, I. (2021). Effects of the irrigation regimes on grapevine cv. Bobal in a Mediterranean climate: I. Water relations, vine performance and grape composition. Agricultural Water Management, 248, 106772. https://doi. org/10.1016/j.agwat.2021.106772

Pines, D., Ditkovich, J., Mukra, T., Miller, Y., Kiefer, P. M., Daschakraborty, S., Hynes, J., \& Pines, E. (2016). How acidic is carbonic acid? The Journal of Physical Chemistry B, 120(9), 2440-2451. https://doi.org/10.1021/acs.jpcb.5b12428

Rees, R. M., Ball, B. C., Campbell, C. D., \& Watson, C. A. (2001). Sustaining soil organic matter. In R. M. Rees, B. C. Ball, C. D. Campbell, \& C. A. Watson (Eds.), Sustainable management of soil organic matter (pp. 413-425). Cabi Publishing.

Rockwood, D. D., Becker, B., \& Ozores-Hampton, M. P. (2012). Municipal solid waste compost benefits on short rotation woody crops. Compost Science Utilization, 20(2), 67-72. https:// doi.org/10.1080/1065657X.2012.10737027

Rodrigues, M. A., \& Arrobas, M. (2020). Cover cropping for increasing fruit production and farming sustainability. In A. K.
Srivastava, \& C. Hu (Eds.), Fruit crops: diagnosis and management of nutrient constraints (pp. 279-295. Elsevier.

Rodrigues, M. A., Dimande, P., Pereira, E., Ferreira, I. Q., Freitas, S., Correia, C. M., Moutinho-Pereira, J., \& Arrobas, M. (2015). Early-maturing annual legumes: an option for cover cropping in rainfed olive orchards. Nutrient Cycling in Agroecosystems, 103, 153-166. https://doi.org/10.1007/s10705-015-9730-5

Santos, J. Q. (2015). Fertilização: fundamentos agroambientais da utilização dos adubos e corretivos. Publindústria. (in Portuguese).

Sigler, W. A., Ewing, S. A., Jones, C. A., Payn, R. A., Miller, P., \& Maneta, M. (2020). Water and nitrate loss from dryland agricultural soils is controlled by management, soils, and weather. Agriculture, Ecosystems \& Environment, 304, 107158. https:// doi.org/10.1016/j.agee.2020.107158

Temminghoff, E. E. J. M., \& Houba, V. G. (2004). Plant analysis procedures. Kluwer Academic Publishers.

Torres, M.- A.- R.-R., Ordóñez-Fernández, R., Giráldez, J. V., Márquez-García, J., Laguna, A., \& Carbonell-Bojollo, R. (2018). Efficiency of four different seeded plants and native vegetation as cover crops in the control of soil and carbon losses by water erosion in olive orchards. Land Degradation \& Development, 29, 2278-2290. https://doi.org/10.1002/ldr.3023

Van Reeuwijk, L. P. (2002). Procedures for soil analysis (6th ed.). Technical Paper 9. ISRIC, FAO.

Weil, R. R., \& Brady, N. C. (2017). The nature and properties of soils (15th ed.). Pearson.

White, P. J. (2012). Ion uptake mechanisms of individual cells and roots: Short-distance transport. In P. Marschner (Ed.), Marschner's mineral nutrition of higher plants (pp. 7-48). Elsevier.

How to cite this article: Arrobas, M., Thais Nepomuceno Carvalho, J., Raimundo, S., Poggere, G., \& Rodrigues, M. Â. (2021). The safe use of compost derived from municipal solid waste depends on its composition and conditions of application. Soil Use and Management, 00, 1-12. https://doi.org/10.1111/sum.12737 